\title{
Prevalence of herpes simplex, varicella zoster and Cytomegalovirus in tumorous and adjacent tissues of patients, suffering from colorectal cancer in Iran
}

\author{
Shaian Tavakolian ${ }^{1,2}$, Hossein Goudarzi $^{2}$, Behrang Kazeminezhad ${ }^{3}$ and Ebrahim Faghihloo ${ }^{2^{*}}$ (D)
}

\begin{abstract}
Background: Colorectal cancer (CRC) can be considered as a result of multiple risks factors, and the significant role of infectious ones, especially viral diseases could not be underestimated. Despite endorsed attempts to identify the accelerating effects of different herpes viridea, such as HSV-1, HSV2, VZV and CMV on the deterioration of different kinds of malignancy, the relationship between these viruses and CRC have not successfully been understood. Taking advantages of these facts, we assessed the role of these viruses on CRC progression.

Methods: In this case-control study, 88 cancerous specimens and 70 their adjacent paraffin-embedded tissues from Modares Hospital between 2011 and 2019 were collected. We extracted the DNA of each tissue and investigated the presence of HSV-1, HSV2, VZV and CMV.

Results: Our data indicated the presence of HSV-1 DNA in the three control samples; however, we could not find an obvious relationship between HSV2, VZV, CMV infection and this type of cancer. The presence of HSV-1 DNA in control tissues introduced HSV-1 as a probable factor for the killing of colorectal cancer cells.

Conclusions: we supposed that HSV-1 can function as an inhibitor of colon cancer progresion, but it is required to studied more in order to find the role of this virus on CRC.
\end{abstract}

Keywords: HSV-1, HSV-2, VZV, CMV, Colorectal cancer, Viral infectious

\section{Introduction}

Colorectal cancer (CRC) is one of the most daunting health problems in the word. In 2012, it was reported, 1.4 million new cases were suffering from CRC, and more than 700,000 patients died due to this type of cancer [1]. Unfortunately, the symptoms of CRC are usually silent until the mass reaches a large size. The prevalence of CRC is high-frequency in America, NorthWestern Europe, Australia, Japan, China, Singapore, and Canada, and the lower one is reported in African and Asian countries, including Iran (third common malignancy in Iran) [2-4]. The National Colorectal Cancer Roundtable in 2015 suggested, there was an upward

\footnotetext{
* Correspondence: faghihloo@gmail.com

${ }^{2}$ Department of Microbiology, School of Medicine, Shahid Beheshti University of Medical Sciences, Tehran, Iran

Full list of author information is available at the end of the article
}

tendency in the CRC prevalence, and it could reach up to $80 \%$ [5]. Some kinds of therapeutic trends, such as surgery, radiation and chemotherapy have considerable outcome for these patients. Three forms of adenomatous polyps, such as tubular histology, villus, and tubular villus can convert into CRC. Along with genetic risk factors, environmental ones may involve in CRC pathogenesis [6-8]. These environmental risk factors are included in, high fat diet, obesity, family history, red meat consumption, smoking, alcohol consumption, kRAS mutation, inactivation of tumor suppressor genes, MLH1 and MSH2 mutations, perturbation in DNA methylation, microsatellite and last but not least, infectious diseases [9-11].

Nowadays it is supposed, there is a strong relationship between infectious risk factors and different kinds of cancers [12]. it is well-established that Helicobacter 
pylori infection is associated with gastric cancer development [13]. Moreover, Herpes viridea may has accelerating effects on gastric cancer progression [14]. In 90.2\% of stomach cancer cases, the DNA of Epstein-Barr virus (EBV) was detected; however, $11 \%$ of them have EBVencoded small RNAs (EBERs) [15-17]. Herpes viridea is classified as double-stranded DNA family viruses and with different mechanisms is able to escape from immune system [18]. Varicella zoster virus (VZV), Herpes simplex virus type 1 (HSV-1), type 2 (HSV-2) and cytomegalovirus (CMV) are the most known members of this virus family, and have a potential to infect and establish persistent infections in the host. Herpesviridae family has different proteins, including EBNA-1 which can deregulate the cell proliferation control [19]. Researchers have studied on different mechanisms of virus and cancer progression, but the relationship between herpes viridea and CRC is not clear. In this study, it was tempting to assess the prevalence of these viruses in CRC tissues.

\section{Materials and methods Sample information}

In this case-control study, we enrolled 88 adenocarcinoma tumor and 70 normal adjacent tissues $(10 \mathrm{~cm}$ away from tumor) at Modaress Hospital, Tehran, Iran. Table 1 is demonstrated all data. At least two expert resident pathologists confirmed the stage of cancer tissues. [IR.SBMU.RETECH.REC.1397.455 (Grant no 12860)].

\section{DNA extraction}

To extract DNA from each sample, phenol-chloroform procedure was used. At the first step, $1 \mathrm{ml}$ xylene for $3 \mathrm{~h}$ removed paraffin. Then, the digesting buffer containing proteinase $\mathrm{K}$ digested specimens at $37^{\circ \mathrm{C}}$ overnight. After that, phenol (CinnaClon Co., Iran), phenol-chloroform and chloroform employed to discharge protein, and finally ethanol caused DNA precipitation.

Table 1 Samples characteristics of patients

\begin{tabular}{llc}
\hline Pathologic site & Tumor samples & Control samples \\
\hline Gender & 50 & 29 \\
Male & 38 & 41 \\
Female & & \\
Differentiation & 22 & \\
Well adenoma & 38 & \\
Moderate adenoma & 28 & 3 \\
Poor adenoma & 0 & 67 \\
Positive HSV & 88 & \\
Negative HSV & & \\
\hline
\end{tabular}

\section{PCR for $\beta$-globin gene}

We evaluated the quality of DNA extraction by PCR with $\beta$-globin gene. In $25 \mu \mathrm{l}$ containing $12.5 \mu \mathrm{l}$ master mix, $1 \mu \mathrm{l}$ forward and reverse primer $(10 \mathrm{pmol}), 1 \mu \mathrm{l}$ DNA and $8.5 \mu \mathrm{l}$ sterile water, PCR reaction was done, and in $5 \mathrm{~min}$ in $95^{\circ \mathrm{C}}$ as first denaturation, 30 cycles of $95^{\mathrm{oC}}$ for $30 \mathrm{~s}, 55^{\mathrm{oC}}$ for $30 \mathrm{~s}, 72^{\mathrm{oC}}$ for $30 \mathrm{~s}$ and $72^{\circ \mathrm{C}}$ for 7 min., all samples were incubated. The PCR product was $100 \mathrm{bp}$, and every positive human $\beta$-globin gene tissue was taken to detect HSV-1, HSV2, CMV and VZV.

\section{PCR}

We detected CMV, HSV-1,2 and VZV by Bio Intellectica PCR. For amplifying CMV DNA, $12.5 \mu \mathrm{l}$ master mix PCR, $1 \mu \mathrm{l}$ of CMV forward and reverse primer, $3 \mu \mathrm{l}$ DNA, and $7.5 \mu$ sterile water were mixed to make PCR reaction. The PCR schedule template was: $5 \mathrm{~min}$ at $95^{\circ \mathrm{C}}$, then 30 cycles of $95^{\circ} \mathrm{C}$ for $30 \mathrm{~s}, 55^{\circ} \mathrm{C}$ for $30 \mathrm{~s}, 72^{\circ} \mathrm{C}$ for $30 \mathrm{~s}$ and $72^{\circ} \mathrm{C}$ for $10 \mathrm{~min}$. Furthermore, to detect HSV-1 and HSV2, we combined $25 \mu \mathrm{l}$ master mix, $0.5 \mu \mathrm{l}$ forward primer, $0.5 \mu \mathrm{l}$ reverse primer, $21 \mu \mathrm{l}$ sterile water and $3 \mu \mathrm{l}$ sample DNA in final $50 \mu \mathrm{l}$. We employed schedule template in $5 \mathrm{~min}$ initial denaturation at $95^{\circ} \mathrm{C}, 35$ cycles of denaturation at $95^{\circ} \mathrm{C}$ for $1 \mathrm{~min}$, annealing at $55^{\circ} \mathrm{C}$ for 1 min, extension at $72{ }^{\circ} \mathrm{C}$ for $1 \mathrm{~min}$, and final extension at $72^{\circ} \mathrm{C}$ for $7 \mathrm{~min}$. Also to evaluate the existence of VZV in the DNA of extracted samples, in final $25 \mu \mathrm{l}, 12.5 \mu \mathrm{l}$ master mix, $1 \mu \mathrm{l}$ forward primer, $1 \mu \mathrm{l}$ reverse primer, $7.5 \mu \mathrm{l}$ sterile water and $3 \mu \mathrm{l}$ sample DNA were mixed. $5 \mathrm{~min}$ initial denaturation at $94^{\circ} \mathrm{C}, 40$ cycles of denaturation at $94^{\circ} \mathrm{C}$ for $1 \mathrm{~min}$, annealing at $55^{\circ} \mathrm{C}$ for $1 \mathrm{~min}$, extension at $72^{\circ} \mathrm{C}$ for $1 \mathrm{~min}$, and final extension at $72^{\circ} \mathrm{C}$ for $7 \mathrm{~min}$ was employed as PCR schedule template. After that the PCR products of CMV, HSV-1, HSV-2, VZV with the size of 921, 240, 715 and $934 \mathrm{bp}$, respectively, was run into $1.5 \%$ gele electrophoresis primers are presented in Table 2.

\section{Statistical analysis}

To analysis the results obtained from the present study, IBM SPSS Statistics software version 22 and Chi-square test to evaluate the correlation between the prevalence of HSV-1 and patient's sex and age were used.

Table 2 The primers of PCR

\begin{tabular}{ll}
\hline PCR-HSV1-F & GACTCTCCCACCGCCATCAG \\
\hline PCR- HSV1-R & TGTCTTCGGGCGACTGGTCT \\
PCR- HSV2-F & TATGCCTATCCCCGGTTGGA \\
PCR - HSV2-R & CGTGCCATCCGAATAAACGTG \\
PCR-VZV-F & TTGTGTCGGTCTCTCCAAGC \\
PCR-VZV-R & TACGTCTTCAACCTCACGCC \\
PCR-CMV-F & TGGCTITTCTTAACGTGCG \\
PCR-CMV-R & CCTTGACGCTGGTTGGTTG \\
\hline
\end{tabular}


Moreover, to confirm the relation between age and HSV-1 infection, ANOVA test was performed. Experimental data were expressed by mean \pm standard deviation of three independent assays. $P$-value less than $(P<0.05)$ was used as statistically significant.

\section{Results}

To find the relationship between herpes viridea, such as HSV-1, HSV-2, VZV, CMV and CRC, we detected these viruses in colorectal embedded paraffin tissues in Iran. Our samples included, 50 male and 38 female, with the mean ages of 55 years old for men and 51 years old for women (Table 1). The quality of extracted DNA was confirmed by $\beta$-globin, as an internal control. (Fig. 1) Different PCR temperature profiles for detecting CMV, HSV-1, HSV-2 and VZV were used. We found the DNA of HSV-1 in 3 normal tissues (adjacent of the 2 moderate and 1 poor adenocarcinoma tissues - mean age of 55 years old). The pathologic data shown, there were 22 patients with well adenoma, 38 moderate and 28poor adenocarcinoma were diagnosed (Table 1). Our results indicated none of the CMV, HSV-2 and VZV may have significant association with CRC. (Fig. 2).

\section{Discussion}

CRC is one of the major health problems worldwide, and responsible for the high mortality in the world. Although considerable numbers of studies were focused on CRC, myriad mechanisms of CRC progression are yetto-be known. It has reported, many risk factors, especially infectious one, can contribute to CRC progression. Different oncovirus proteins are supposed to intercept some biologic mechanisms in cell with the effects spanning from deregulation of cellular growth to significant roles in the primary step of wide range of human cancers [12]. In this study, 88 adenocarcinoma tumor and 70 normal adjacent tissues were collected to detect the prevalence of CMV, VZV and HSV-1,2. The limitation of this study is the low number of sample.

Previous studies have described that herpes viridea can induce some types of cancers, and authorities have indicated, CMV genes may be able to deregulate the cell cycle mechanisms. Although some investigations indicated the role of this virus on colorectal cancer, some different studies shown, the prevalence of this virus in CRC tissues are too low, which was similar to our results as we did not find any CMV DNA. In the study of Akintola-Ogunremi et al. there was no CMV DNA in 23, 65, and 51 cases of colorectal hyperplastic polyps, colorectal adenomas and colorectal adenocarcinomas, respectively [20]. Sahar Mehrabani-Khasraghi who studied on CRC in Iran also did not diagnose any DNA of this virus [21]. Knösel and et al. studied on 57 primary tumors and 20 metastases, by PCR and immunohistochemistry, and only four primary tumors indicated the CMV infection [22]. In the another study conducted by Rüger, CMV DNA in cancerous and normal tissues were same, and they did not find any relationship between CRC and CMV [23]. Additionally, Hart and et al. investigated on the association of this virus and Frozen sections of 14 specimens by in situ hybridisation using 3H-labelled CMV-DNA as a probe, but their results shown this virus may not have a link with CRC [24]. With the method of nested-PCR that amplifies part of the gB gene of CMV, (57.1\%) of enteric tissue samples of patients with UC were infected by CMV, yet there is no CMV DNA in cancerous tissues [25]. On the other hand the other studies conflict with these results, and reported

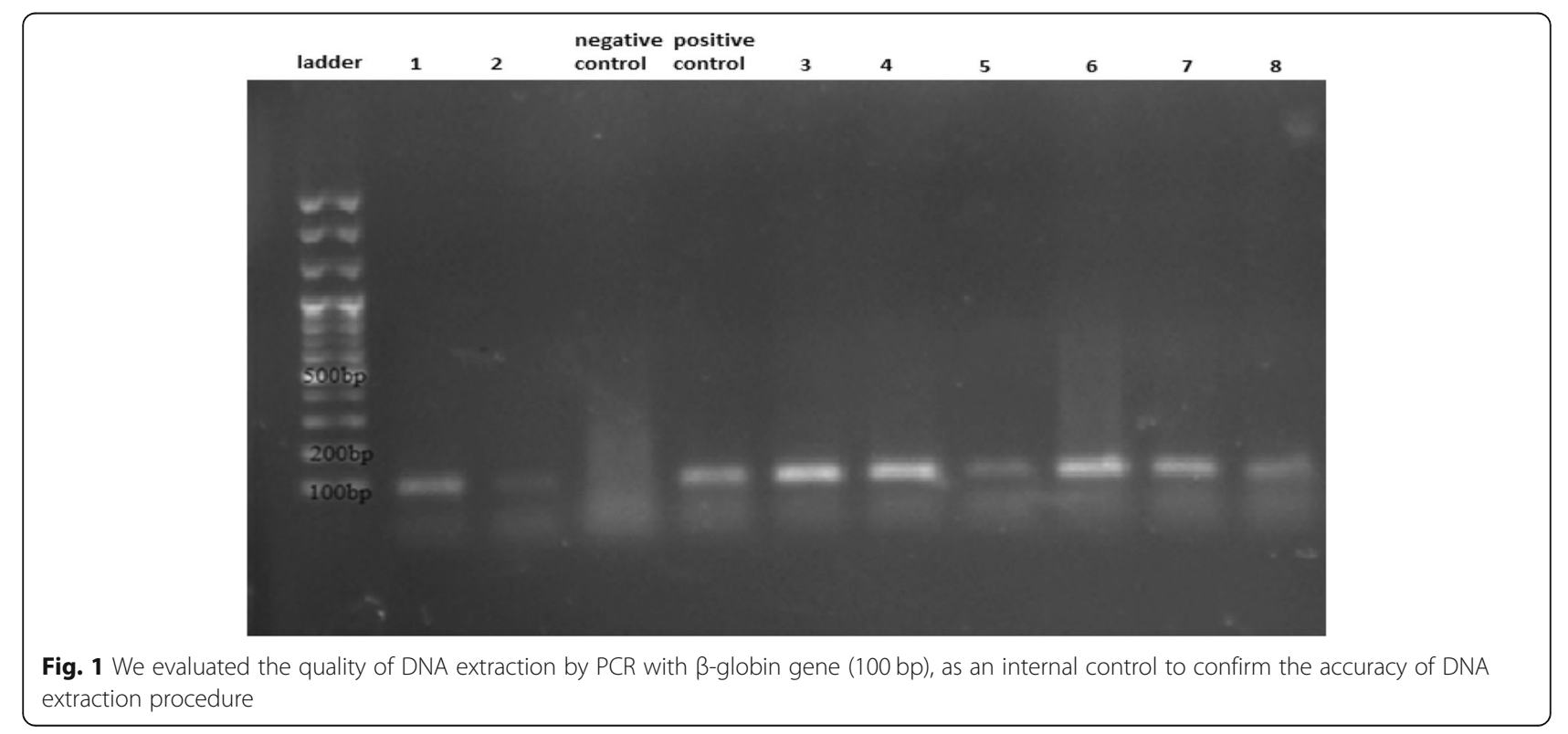




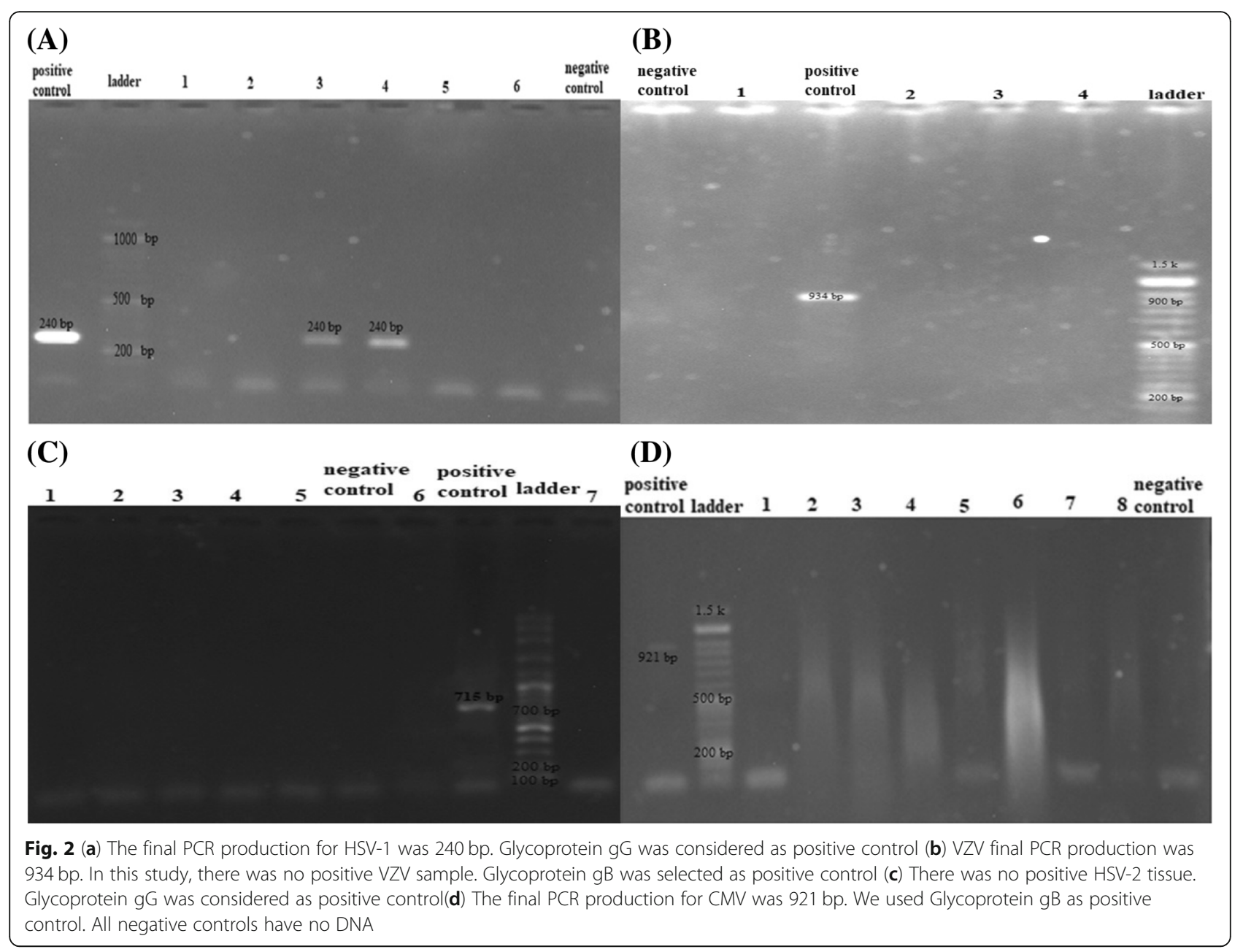

that CMV DNA may be presented in CRC tissues. Huang and Roche detected CMV DNA in 4 out of 7 in colonic cancerous samples [26]. Also it was reported that the DNA of CMV was detected in adenomatous polyposis, but not found in normal tissues [27]. By nested PCR, 6 of the 56 CRC tissues were infected by CMV DNA; furthermore, there were $6 \mathrm{CMV}$ infected cases of adenoma and moderately differentiated adenocarcinoma, but it was not detected any CMV DNA in well and poorly differentiated adenocarcinomas [28]. In the study on the cancerous and paired normal tissue from Swedish and Vietnamese CRC patients, CMV DNA was found in 39.8\% of Vietnamese patients and $15.1 \%$ in Swedish ones [29]. Chen HP detected CMV by PCR in CRC tissues (42.3\%) higher than in normal colorectal specimen (5.6\%) [30]. Among 95 ulcerative colitis samples which were analyzed, 33 tissues were indicated the presence of CMV and 62 specimen were CMV negative [31].

Varicella-zoster virus is classified as one of the members of herps viridea that able to hide in nerve cells and resume activity in times of stress [32]. In this study, we investigated the presence of VZV DNA by PCR, and it was not find in any CRC samples and normal ones. Mahale $\mathrm{P}$ claimed the prevalence of this virus in CRC was (aOR, 1.10; 95\% CI, 1.02-1.19), in elderly patients [33]. In 2003 it was reported, 5 out of 131 patients who had gastrointestinal or colon cancer indicated the VZV DNA [34]. Since more therapies, such as radiation, treatment with arsenic trioxide, chemotherapy in different types of cancers can stimulate the cell, and ultimately, increase the reactivity of this virus, investigations were focused on the role of this virus in different kind of cancers, in the stress time. In the study of Nouri, it was reported in patients who was treated with arsenic trioxide, VZV can reactivate and contribute myeloma and colon cancer [32]. Yo-Liang Lai declared, there was an increase in the risk of varicella-zoster virus infection in patients, suffering from breast cancer after adjuvant radiotherapy [35]. However some studies claimed VZV is able to cause Inflammatory bowel disease (IBD), or more severe disease in colon. It is supposed, the prevalence of VZV in immunosuppressed IBD patients (particularly men aged 35-44/65 years and over) is considerable [36]. Also it was reported, there is more chances to diagnose VZV 
in patients with the symptoms of Crohn's disease (CD) and ulcerative colitis (UC) [37].

In our study, we detected the presence of HSV-1 in 3 control tissues, which is similar to the results of others. Actually different studies suggested, HSV can lead to necrosis in tumor cel [38]. Many investigations even discussed about the role of this virus in treatment of colon cancer [39]. The combination of interleukin IL-18 and herpes simplex virus-thymidine kinase (HSV-TK) can increase in the human telomerase reverse transcriptase (hTERT) promoter activity in a murine, and finally eradicate the colorectal tumor [40]. NV1023 (multi mutant HSV) and NV1042, formed by insertion of the mIL12 gene into NV1023, may have a antitumor activity [41]. Using disks containing this virus (DISC-HSV), as a vector, may result in killing the tumor cell, and ultimately cause decrease in cancer progression [42]. The substitution rate for HSV-1 is approximately $1.38 \times 10(-7)$ subs/site/year in six clades, which Preferentially targets Human Colon Carcinoma [43]. Furthermore, collagen and mucin molecules in healthy colon tissues are able to limit the HSV-1 infection, but the lack of expression of these molecule in cancerous tissues results in activation of HSV-1 [44]. Fong Y and et al. found Multi mutated HSV (NV1020) is able to replicate in colon cancer tissues, and reduce the tumor marker carcinoembryonic antigen (CEA) with the rate of (median $\%$ drop $=24 \%$; range $13-74 \% ; P<0.02)$ [45]. The combination of $(\mathrm{HSV}$ TK)-suicide gene therapy and interleukin-21 (IL-21) may be one of the best gene therapy in colon tumors [46].

\section{Conclusion}

In conclusion according to the above mentioned content, we supposed some different mechanisms of HSV which can be involved in the reduction of CRC progression, and kill the colon tumor cells, but further investigation is needed to warrant, and provide valuable clues to consider this virus as a factor of treatment process.

\section{Abbreviations}

CMV: Cytomegalovirus; CRC: Colorectal cancer; HSV-1: Herpes Simplex virus type 1; HSV-2: Herpes Simplex virus type 2; VZV: Varicella zoster virus

\section{Acknowledgements}

we would appreciate Infectious Diseases and Tropical Medicine Research Center, Shahid Beheshti University of Medical Sciences.

\section{Authors' contributions}

EF and SHT designed the study and performed the cell culture and the molecular experiments. HG and BK performed the statistical Analyses. All authors read and approved the final version of the manuscript.

\section{Funding}

This study was approved by the Shahid Beheshti University of Medical Sciences" IR.SBMU.RETECH.REC.1397.455 (Grant no 12860) and has a role in analysis data.

Availability of data and materials

Please contact author for data requests.
Ethics approval and consent to participate

This study has been conducted in Department of the School of Medicine Shahid Beheshti University of Medical.

\section{Consent for publication}

The consent for publications was obtained from all patients.

\section{Competing interests}

The authors declare no conflicts of interests.

\section{Author details}

${ }^{1}$ Infectious Diseases and Tropical Medicine Research Center, Shahid Beheshti University of Medical Sciences, Tehran, Iran. ${ }^{2}$ Department of Microbiology, School of Medicine, Shahid Beheshti University of Medical Sciences, Tehran, Iran. ${ }^{3}$ Department of Pathology, Clinical Research Development Center, Shahid Modarres Hospital, Shahid Beheshti University of Medical Science,

Tehran, Iran.

Received: 7 October 2019 Accepted: 11 December 2019

Published online: 30 December 2019

\section{References}

1. Torre LA, Bray F, Siegel RL, Ferlay J, Lortet-Tieulent J, Jemal A. Global cancer statistics, 2012. CA Cancer J Clin. 2015;65(2):87-108.

2. Rezaianzadeh A, Safarpour AR, Marzban M, Mohaghegh A. A systematic review over the incidence of colorectal cancer in Iran. Annals of colorectal research. 2015;3(1):e25724.

3. Haghdoost A, Chamani G, Zarei MR, Rad M, Hashemipour M, Marzban M. Low Incidence of Colorectal Cancer in Kerman Province, Iran. Iran J Cancer Prev. 2011;4(1).

4. Fakheri $\mathrm{H}$, et al. The epidemiologic and clinical-pathologic characteristics of colorectal cancers from 1999 to 2007 in sari, Iran. J Mazand Univ Med Sci. 2008;18(67):58-66.

5. Sy AU, Lim E, Ka'opua LS, Kataoka-Yahiro M, Kinoshita Y, Stewart SL. Colorectal cancer screening prevalence and predictors among Asian American subgroups using medical expenditure panel survey National Data. Cancer. 2018;124(Suppl 7):1543-51.

6. Faghihloo E, Sadeghizadeh M, Shahmahmoodi S, Mokhtari-Azad T. Cdc6 expression is induced by HPV16 E6 and E7 oncogenes and represses Ecadherin expression. Cancer Gene Ther. 2016.

7. Markowitz SD, Bertagnolli MM. Molecular origins of cancer: molecular basis of colorectal cancer. N Engl J Med. 2009;361 (25):2449-60.

8. Tavakolian S, Goudarzi H. Eslami G1, Faghihloo E. transcriptional regulation of epithelial to Mesenchymal transition related genes by lipopolysaccharide in human cervical Cancer cell line HeLa. Asian Pac J Cancer Prev. 2019;20(8): 2455-61.

9. Faghihloo E, Yavarian J, Jandaghi NZ, Shadab A, Azad TM. Genotype circulation pattern of human respiratory syncytial virus in Iran. Infect Genet Evol. 2014;22:130-3.

10. Kamiza $A B$, et al. Risk factors associated with colorectal cancer in a subset of patients with mutations in MLH1 and MSH2 in Taiwan fulfilling the Amsterdam II criteria for lynch syndrome. PLoS One. 2015;10(6):e0130018.

11. Mirzaei H, Faghihloo E. Viruses as key modulators of the TGF- $\beta$ pathway; a double-edged sword involved in cancer. Rev Med Virol. 2018;28(2).

12. Vaezjalali M, Rashidpour S, Rezaee H, Hajibeigi B, Zeidi M, Gachkar L, et al. Hepatitis B viral DNA among HBs antigen negative healthy blood donors. Hepat Mon. 2013;13(3):e6590.

13. Parsonnet J, et al. Helicobacter pylori infection and the risk of gastric carcinoma. N Engl J Med. 1991;325(16):1127-31.

14. Chen X-Z, Chen H, Castro FA, Hu J-K, Brenner H. Epstein-Barr virus infection and gastric Cancer. Medicine (Baltimore). 2015;94(20):e792.

15. Nogueira, C, Mota M, Gradiz R, Augusta Cipriano M, Caramelo F, Cruz H, et al. Prevalence and characteristics of Epstein-Barr virus-associated gastric carcinomas in Portugal. Infect Agent Cancer. 2017;12:41.

16. Faghihloo E, Saremi MR, Mahabadi M, Akbari H, Saberfar E. Prevalence and characteristics of Epstein-Barr virus-associated gastric cancer in Iran. Arch Iran Med. 2014;17(11):767-70.

17. Mirzaei H, Goudarzi H, Eslami G, Faghihloo E. Role of viruses in gastrointestinal cancer. J Cell Physiol. 2018;233(5):4000-14.

18. Brizzi KT, Lyons JL. Peripheral nervous system manifestations of infectious diseases. Neurohospitalist. 2014;4(4):230-40. 
19. Morris MA, Dawson CW, Young LS. Role of the Epstein-Barr virus-encoded latent membrane protein-1, LMP1, in the pathogenesis of nasopharyngeal carcinoma. Future Oncol. 2009;5(6):811-25.

20. Akintola-Ogunremi O, Luo Q, He TC, Wang HL. Is cytomegalovirus associated with human colorectal tumorgenesis? Am J Clin Pathol. 2005; 123(2):244-9.

21. Mehrabani-Khasraghi S, Ameli M, Khalily F. Demonstration of herpes simplex virus, Cytomegalovirus, and Epstein-Barr virus in colorectal Cancer. Iran Biomed J. 2016;20(5):302-6. Epub 2016 May 25.

22. Knösel T, Schewe C, Dietel M, Petersen I. Cytomegalovirus is not associated with progression and metastasis of colorectal cancer. Cancer Lett. 2004; 211(2):243-7.

23. Rüger R, Fleckenstein B. Cytomegalovirus DNA in colorectal carcinoma tissues. Klin Wochenschr. 1985;63(9):405-8.

24. Hart H, Neill WA, Norval M. Lack of association of cytomegalovirus with adenocarcinoma of the colon. Gut. 1982;23(1):21-30.

25. Mariguela VC, Chacha SG, Cunha Ade A, Troncon LE, Zucoloto S, Figueiredo LT. Cytomegalovirus in colorectal cancer and idiopathic ulcerative colitis. Rev Inst Med Trop Sao Paulo. 2008;50(2):83-7.

26. Huang ES, Roche JK. Cytomegalovirus DNA and adenocarcinoma of the colon: evidence for latent viral infection. Lancet. 1978;1(8071):957-60.

27. Bender C, Zipeto D, Bidoia C, Costantini S, Zamo A, Menestrina F, Bertazzoni $U$. Analysis of colorectal cancers for human cytomegalovirus presence. Infectious agent cancer. 2009;4:6.

28. Gershon AA, Breuer J, Cohen Jl, Cohrs RJ, Gershon MD. Varicella zoster virus infection. Nat Rev Dis Primers. 2015;1:15016.

29. Dimberg J, Hong T, Skarstedt M, Löfgren S, Zar N, Matussek A. Detection of cytomegalovirus DNA in colorectal tissue from Swedish and Vietnamese patients with colorectal cancer. Anticancer Res. 2013; 33(11):4947-50

30. Chen HP, Jiang JK, Chen CY, Chou TY, Chen YC, Chang YT, et al. Human cytomegalovirus preferentially infects the neoplastic epithelium of colorectal cancer: a quantitative and histological analysis. J Clin Virol. 2012; 54(3):240-4.

31. Zagórowicz E, Bugajski M, Wieszczy P, Pietrzak A, Magdziak A, Mróz A. Cytomegalovirus infection in ulcerative colitis is related to severe inflammation and a high count of Cytomegalovirus-positive cells in biopsy is a risk factor for colectomy. J Crohns Colitis. 2016;10(10):1205-11.

32. Nouri K, Ricotti CA Jr, Bouzari N, Chen H, Ahn E, Bach A. The incidence of recurrent herpes simplex and herpes zoster infection during treatment with arsenic trioxide. J Drugs Dermatol. 2006;5(2):182-5.

33. Mahale P, Yanik EL, Engels EA. Herpes zoster and risk of Cancer in the elderly U.S. population. Cancer Epidemiol Biomark Prev. 2016;25(1):28-35.

34. Yamamoto M, Mine H, Akazawa K, Maehara Y, Sugimachi K. Gastrointestinal cancer and herpes zoster in adults. Hepatogastroenterology. 2003;50(52): 1043-6.

35. Lai YL, Su YC, Kao CH, Liang JA. Increased risk of varicella-zoster virus infection in patients with breast cancer after adjuvant radiotherapy: A population-based cohort study. PLoS One. 2019;14(1):e0209365.

36. Tsai SY, Yang TY, Lin CL, Tsai YH, Kuo CF, Kao CH. Increased risk of varicella zoster virus infection in inflammatory bowel disease in an Asian population: a nationwide population-based cohort study. Int J Clin Pract. 2015;69(2): 228-34.

37. Bye W, Sparrow M, J. Connor S, M. Andrews J, et al. Su1831 Identifying "At Risk" Inflammatory Bowel Disease Patients Who May Be Targeted With a New Adjuvanted Herpes Zoster Subunit Vaccine. 2016;S00165085(16)31930-8.

38. Zhao Q, Zhang W, Ning Z, et al. A novel oncolytic herpes simplex virus type 2 has potent anti-tumor activity. PLoS One. 2014;9(3):e93103.

39. Yang H, Peng T, Li J, Wang Y, Zhang W, Zhang P, et al. Treatment of colon cancer with oncolytic herpes simplex virus in preclinical models. Gene Ther. 2016;23(5):450-9.

40. Higashi K, Hazama S, Araki A, Yoshimura K, lizuka N, Yoshino S, et al. A novel cancer vaccine strategy with combined IL-18 and HSV-TK gene therapy driven by the hTERT promoter in a murine colorectal cancer model. Int J Oncol. 2014;45(4):1412-20.

41. Bennett JJ, Malhotra S, Wong RJ, Delman K, Zager J, St-Louis M, et al. Interleukin 12 secretion enhances antitumor efficacy of oncolytic herpes simplex viral therapy for colorectal cancer. Ann Surg. 2001;233(6):819-26.
42. Todryk S, McLean C, Ali S, Entwistle C, Boursnell M, Rees R, et al. Disabled infectious single-cycle herpes simplex virus as an oncolytic vector for immunotherapy of colorectal cancer. Hum Gene Ther. 1999;10(17):2757-68.

43. Kolb AW, Ané C, Brandt CR. Using HSV-1 genome phylogenetics to track past human migrations. PLoS One. 2013;8(10):e76267.

44. Kolodkin-Gal D, Zamir G, Edden Y, Pikarsky E, Pikarsky A, Haim H, et al. Herpes simplex virus type 1 preferentially targets human colon carcinoma: role of extracellular matrix. J Virol. 2008:82(2):999-1010. Epub 2007 Oct 31.

45. Fong Y, Kim T, Bhargava A, Schwartz L, Brown K, Brody L, Covey A, et al. A herpes oncolytic virus can be delivered via the vasculature to produce biologic changes in human colorectal cancer. Mol Ther. 2009;17(2):389-94.

46. Hanari N, Matsubara H, Hoshino I, Akutsu Y, Nishimori T, Murakami K, et al. Combinatory gene therapy with electrotransfer of midkine promoter-HSV-TK and interleukin-21. Anticancer Res. 2007;27(4B):2305-10.

\section{Publisher's Note}

Springer Nature remains neutral with regard to jurisdictional claims in published maps and institutional affiliations.
Ready to submit your research? Choose BMC and benefit from:

- fast, convenient online submission

- thorough peer review by experienced researchers in your field

- rapid publication on acceptance

- support for research data, including large and complex data types

- gold Open Access which fosters wider collaboration and increased citations

- maximum visibility for your research: over $100 \mathrm{M}$ website views per year

At BMC, research is always in progress.

Learn more biomedcentral.com/submissions 